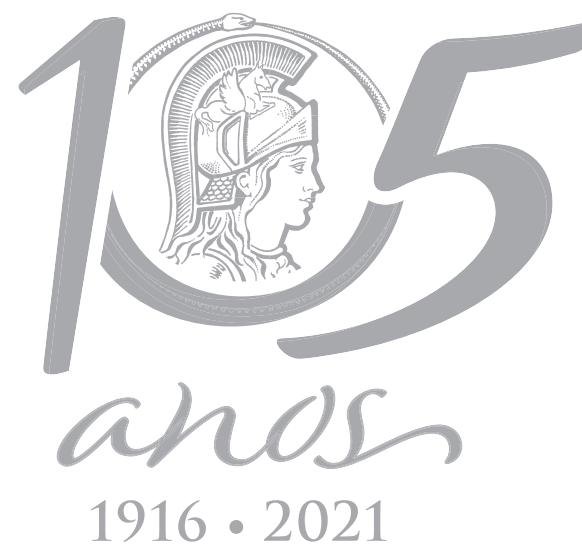

\title{
Assessment of spatial variability of bedding variables in compost bedded pack barns with climate control system
}

\author{
CARLOS EDUARDO A. OLIVEIRA, FLÁVIO A. DAMASCENO, GABRIEL A.S. FERRAZ, \\ JOÃO ANTÔNIO C. DO NASCIMENTO, FELIPE A.O. VEGA, ILDA F.F. TINÔCO \& \\ RAFAELLA R. ANDRADE
}

\begin{abstract}
The aim of this research was to evaluate the spatial distribution of bedding variables in a climate-controlled compost bedded pack barn (CBP) equipped with an evaporative cooling system associated with a tunnel ventilation mode. The study was conducted on a farm in the West Mesoregion of Minas, MG, Brazil. The interior of the animal facility was divided into a mesh of 120 equidistant points, where the bedding surface temperature $\left(\mathrm{t}_{\mathrm{b} \text {-sur }}\right)$, the bedding temperature at $0.20 \mathrm{~m}$ depth $\left(\mathrm{t}_{\mathrm{b}-20}\right)$ and the bedding penetration resistance $\left(\mathrm{PR}_{\mathrm{b}}\right)$ of layer 0 to $0.20 \mathrm{~m}$ depth were measured. Bedding samples were collected to obtain the moisture $\left(\mathrm{M}_{\mathrm{b}}\right)$ and $\mathrm{pH}$ in the surface and at 0.20 $m$ depth. Geostatistics technique was used to evaluate the dependence and spatial distribution. Through the bedding area, the $t_{b \text {-sur }}$ presented low variability, with 6 o $C$ of amplitude, and $t_{b-20}$ presented highest values (up to $55^{\circ} \mathrm{C}$ ). The spatial distribution of $M_{\mathrm{b}-20}$ was similar to that observed on the surface and its highest levels occurred in the region near the feed alley (> 40\%). The distribution of $\mathrm{pH}$ was similar in both layers. The tendency of high $\mathrm{PR}_{\mathrm{b}}$ occurred in the layer between 0.15 and $0.20 \mathrm{~m}$ ( 0 and $1500 \mathrm{kPa}$ ).
\end{abstract}

Key words: dairy cattle, compost barns, geostatistics, spatial variability.

\section{INTRODUCTION}

Greater attention was given to animal comfort as a result of the introduction of genetically developed animals for temperate climates in Brazil, because the country has a tropical climate with high temperatures occurring all year throughout its territory (Faria et al. 2008). In this context, the use of intensive production systems in which animals remain housed in comfortable and functional facilities to provide a comfortable environment, to reduce stress and, consequently, increase the welfare and productive capacity of animals has emerged (Perissinotto et al. 2009).

Among the intensive milk production systems, the compost bedded pack barns (CBP) have been standing out. It is a confinement model in which the animals remain inside a big facility, in a large common area covered by a bed of soft and comfortable material, being free to move and express their natural behaviors (Leso et al. 2013, 2020). Proper design of the CBP has several advantages, such as improved comfort and animal welfare, gains in productivity and herd health, reduced production costs, among others (Black et al. 2013).

The ventilation system is one of the main factors that must be considered to achieve a successful CBP barn. It provides a comfortable environment for the animals, removes gases and heat, and dries the bedding material (Lobeck et al. 2011, Pilatti \& Vieira 2017). The use of adequate 
cooling systems and the correct stirring of the bedding material should allow homogeneity of the variables inside the facility (Massari et al. 2016). However, few studies have been focused to assess and characterize the bed environment in CBP facilities, mainly because the use of this technique is recent in Brazil.

Thus, monitoring and evaluation activities of the environment of the facility are important for the success of the CBP, since they can be used as decision-making tools allowing adjustments and corrections in the installations (Sales et al. 2011). Geostatistical methods stand out among the models used to evaluate the spatial variability. These methods allow the results to be in interpreting based on their spatial variability, understand data randomness and establish spatial dependency functions (Medeiros et al. 2014, Yamamoto \& Landim 2015, Damasceno et al. 2019).

The aim of this research was to evaluate the dependence and spatial distribution of the bedding variables: temperature, moisture, $\mathrm{pH}$ and penetration resistance in a climatecontrolled compost bedded pack barn (CBP) equipped with an evaporative cooling system associated with a tunnel ventilation mode (negative pressure).

\section{MATERIALS AND METHODS}

\section{Characterization and operating conditions of the animal facility}

All methods involving cows were approved by the Ethic Committee in Animal Use of the Universidade Federal de Lavras (Protocol $n^{\circ}$ 014/16). This study was performed during spring of 2017, in a dairy farm with climatecontrolled compost bedded pack barn (CBP). It was located west of the state of Minas Gerais in Brazil (latitude $20^{\circ} 47^{\prime} 30^{\prime \prime} \mathrm{S}$, longitude 45 18' $52^{\prime \prime}$ W, and altitude $921 \mathrm{~m}$ ), northeast-southwest oriented. The CBP dimensions were $180 \mathrm{~m}$ long, $26.5 \mathrm{~m}$ wide, it had a feeding alley of $4.0 \mathrm{~m}$ wide, an eave height of $4.0 \mathrm{~m}$, a roof pitch of $15^{\circ}$ and was roofed with metallic tiles (thickness of 0.50 $\mathrm{mm}$ ), as can be seen from the Figure 1a.

The floor of the feed alley was covered in concrete. The lateral sides were closed by blue color plastics curtains with $3.5 \mathrm{~m}$ of height. Inside the CPB, baffle curtains used to direct the air towards the animals were installed, starting at $2.5 \mathrm{~m}$ in height and spaced every $12 \mathrm{~m}$. The CBP was equipped with 90 tubular fluorescent lamps with $36 \mathrm{~W}$ of power, equally spaced.

The climatized CBP was equipped with an evaporative cooling system associated with a tunnel ventilation mode (negative pressure) with 22 exhaust fans (Equipaves ${ }^{\circledR}$, model 53 in, diameter of $1.42 \mathrm{~m}$, six propellers and $1.0 \mathrm{CV}$ of power) installed in the northeast face of the barn. The cellulose evaporative pad cooling system had dimensions of $3.0 \mathrm{~m}$ high, $18.0 \mathrm{~m}$ wide and $0.15 \mathrm{~m}$ thick. The cooling system was controlled using data from temperature sensors, that were located inside the barn to monitor the environmental conditions. This allowed to remain the system switched on whenever the air temperature was above $21^{\circ} \mathrm{C}$.

325 Holstein cows (305 lactating and 20 precalving) were housed in the CBP. The lactating cows were distributed in 5 groups divided according to the animals milk yield. Larger animals were housed in lots 1 and 2, located near the evaporative pad cooling (Table I). The average milk production per cow was $28 \mathrm{~kg} \cdot \mathrm{day}^{-1}$.

The CBP had a total area of $4770 \mathrm{~m}^{2}$, where $3420 \mathrm{~m}^{2}$ were resting area (wood sawdust with depth of $0.4 \mathrm{~m}$ ). The average stock density was $10.5 \mathrm{~m}^{2} \cdot \mathrm{cow}^{-1}$. The bed stirring was performed twice a day at milking times (7:00 a.m. and 2:00 p.m.) by means of a rototiller with cultivator, coupled to a small tractor (Figure 1b). 


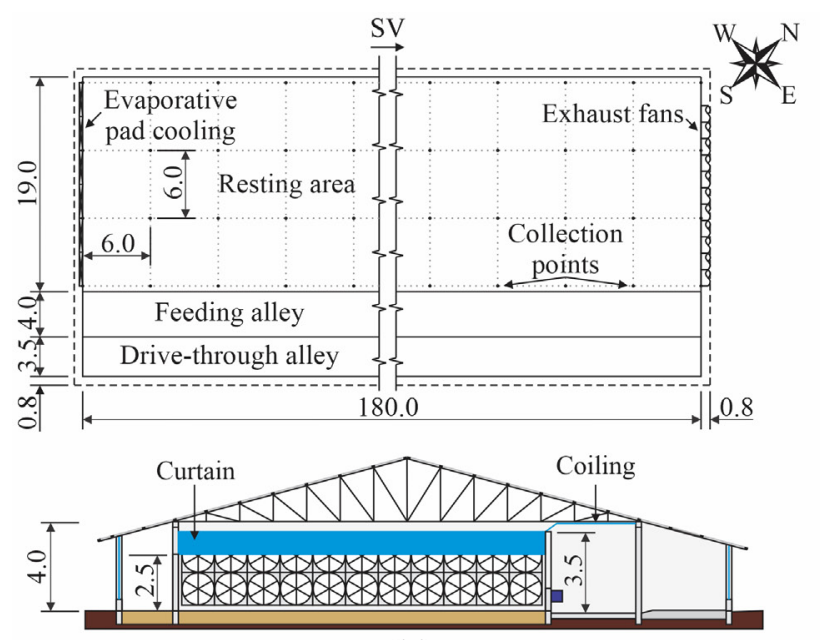

(a)

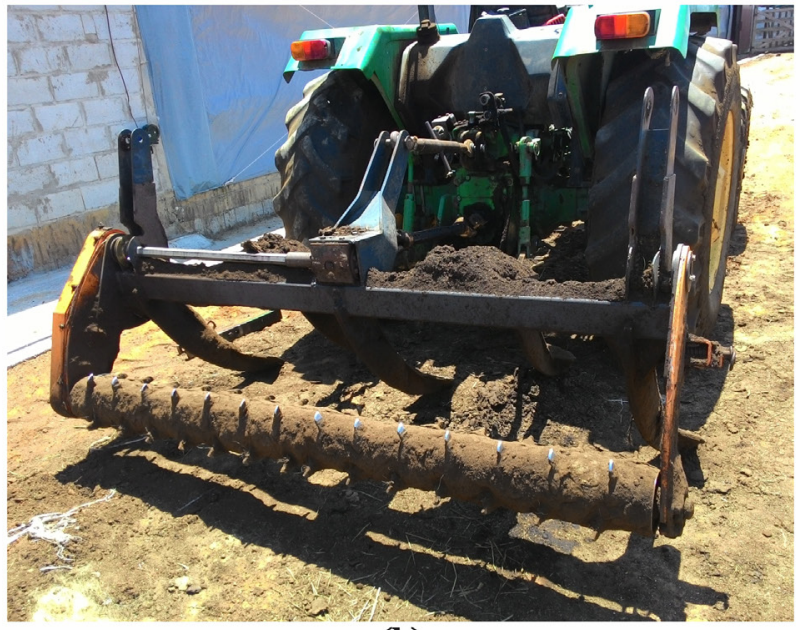

(b)

Figure 1. (a) Schematic representation of the CBP with points of collection of samples and dates and cross section. (b) Rototiller with cultivator used, coupled to a tractor. * $\mathrm{SV}$ - Sense of ventilation. Dimensions in meters (m).

Table I. Individualized information from lots housed inside the CBP ( 5 groups divided according to the animals milk yield).

\begin{tabular}{|c|c|c|c|c|c|c|}
\hline \multirow{2}{*}{ Information } & \multicolumn{6}{|c|}{ Lot } \\
\hline & 1 & 2 & 3 & 4 & 5 & Pre-calving \\
\hline Number of cows in the lot (cows) & 76 & 97 & 62 & 33 & 37 & 20 \\
\hline Bedding area of lot $\left(\mathrm{m}^{2}\right)$ & 855 & 912 & 570 & 399 & 399 & 285 \\
\hline Available area for cow $\left(\mathrm{m}^{2} \cdot \operatorname{cow}^{-1}\right)$ & 11.2 & 9.4 & 9.2 & 12.1 & 10.8 & 14.2 \\
\hline
\end{tabular}

\section{Data collection, bedding sampling and analysis}

The resting area of the CBP was divided into a rectangular grid containing 120 equidistant points $(6 \times 6 \mathrm{~m})$, arranged according to the constructive characteristics of the barn (Figure 1a). The data sampling was performed for 3 consecutive days between 1:00 p.m. to 4:00 p.m. As several variables were measured or sampled, it was necessary to employ up to 3 hours to sample all of them. The stirring of the bed was performed after finishing sampling. It allowed to evaluate the bed in its most critical conditions.

The bedding temperature was measured in two points: in the bed surface and at a depth of $0.2 \mathrm{~m}$. The surface temperature of the bed $\left(t_{b-s u r}\right)$ was measured using a digital infrared thermometer (Ferm ${ }^{\oplus}$ ITM1001, with measuring range from 0 to $300{ }^{\circ} \mathrm{C}$ and $2 \%$ of accuracy). The temperature at $0.2 \mathrm{~m}$ depth $\left(\mathrm{t}_{\mathrm{b}-20}\right)$ was measured with a rod thermometer (Pyromed ${ }^{\oplus}$ TP101, with measuring range from -50 to $300{ }^{\circ} \mathrm{C}$ and $\pm 0.1^{\circ} \mathrm{C}$ of accuracy).

The penetration resistance of the bed was measured using an electronic soil compaction meter (Falker ${ }^{\oplus}$ PLG1020, with programmable resolution of 10,20 and $50 \mathrm{~mm}$, and maximum depth measurement of $0.6 \mathrm{~m}$ ). The soil compaction meter was configured to measure the penetration resistance of the bed at surface and at $0.2 \mathrm{~m}$ depth with a resolution of $10 \mathrm{~mm}$.

Samples of bedding material were collected from the surface layer and from $0.2 \mathrm{~m}$ depth using a post hole digger, to determine their moisture content and $\mathrm{pH}$. The material collected 
were stored individually in hermetic plastic bags and properly identified. These samples were analyzed in the Rural Construction Laboratory of the Universidade Federal de Lavras, Minas Gerais, Brazil.

The $\mathrm{pH}$ of the bedding material samples was measured using $10 \mathrm{~g}$ of compost in $25 \mathrm{ml}$ of distilled water (1.0:2.5 ratio). The mixture obtained was shaken for 3 to $5 \mathrm{~min}$, and then left to rest for 30 min before taking the $\mathrm{pH}$ measurement (Zhao et al. 2012). A calibrated digital pH meter bench (Even ${ }^{\oplus} \mathrm{PHS}-3 \mathrm{E}$, with measuring range from 0 to 14 and \pm 0.01 of accuracy) was employed for the $\mathrm{pH}$ measurements.

The gravimetric method was used to determine the moisture content of bedding material. Samples of $10 \mathrm{~g}$ were arranged in porcelain containers and their mass with and without bedding material was measured. The containers were transferred to an oven at 105 ${ }^{\circ} \mathrm{C}\left( \pm 5{ }^{\circ} \mathrm{C}\right)$ for $24 \mathrm{~h}$ or until a constant mass was obtained. Then, the samples were placed in a desiccator for $30 \mathrm{~min}$ approximatelly, until the environmental temperature was achieved. Finally, the measurement of the container and dry bedding material was made (Teixeira et al. 2017). An analytical scale with measuring capacity of $120 \mathrm{~g}$ and $\pm 0.0001 \mathrm{~g}$ of accuracy was used. The moisture content was determined using the ratio between the mass of water evaporated and the bed dry sample and converted to percentage.

\section{Geostatistical analysis}

The geostatistics method was used to identify the spacial dependency of the variables, to estimate their levels and to determine their spatial distribution inside the facility. The computational software $R$ Development Core Team (2016) through the geoR library was employed for analyzes. Semiovariograms were fitted using the Matheron's estimator (1962) to quantify the spatial dependency of the variables inside the facility:

$$
\hat{\gamma}(h)=\frac{1}{2 N(h)} \sum_{i=1}^{N(h)}\left[Z\left(X_{i}\right)-Z\left(X_{i}+h\right)\right]^{2}
$$

where $\hat{\gamma}(h)$ is the semivariance, $N(h)$ is the number of experimental pairs of observations $Z\left(X_{i}\right)$ and $Z\left(X_{i}+h\right)$ at locations $X_{i}$ and $X_{i}+h$, separated by the distance $h$.

From the computed values of $\hat{\gamma}(h)$, the parameters of a theoretical model of the semivariogram were obtained, according to Bachmaier \& Backers (2008). They were the nugget effect $\left(C_{0}\right)$, sill $\left(C_{0}+C_{1}\right)$ and range of influence (a). Ferraz et al. $(2016,2020)$ and Ribeiro et al. (2016) studied the spatial distribution in animal facilities and concluded that the spherical model had the best fit, because of its relatively easy ability to adjust to any cloud point. The method of Restricted Maximum Likelihood (REML) was employed to fit the data, because it allowed a less biased estimate for small data cluster (Marchant \& Lark 2007).

The Spatial Dependency Index (SDI) was used to analyze the spatial dependency of the variables. It was computed from the ratio between the nugget effect $\left(C_{0}\right)$ and the sill $\left(C_{0}+C_{1}\right)$. The SDI was determined using the Cambardella et al. (1994) classification, that considered a strong dependency in semivariograms with SDI $\leq 0.25$, moderated dependency in semivariograms with $0.25<\mathrm{SDI} \leq 0.75$ and weak dependency in semivariograms with $\mathrm{SDI}>0.75$.

The method of ordinary kriging was used to interpolate the values of the variable inside the facility at positions that were not measured. This allowed plotting detailed maps of spatial distributions of the variables inside the facility. Thematic maps with class distribution according to the analyzed variable were generated employing the ArqGIS ${ }^{\oplus}$ software (10.1 version), licensed to the Departamento de Engenharia of 
the Universidade Federal de Lavras. Descriptive statistic was used to quantify the area occupied by each class of the variables, allowing improving the characterization of the variables inside the facility.

\section{RESULTS AND DISCUSSION}

The parameters of the experimental semivariogramas fitted to the spherical model using the REML method are summarized in the Table II, for each variable studied.

Because the nugget effect $\left(C_{0}\right)$ indicates the variability not explained (Ferraz et al. 2017a), it was used to determine the discontinuity of the semivariograms for greater distances than the distance between the sample points. This discontinuity may be attributed to errors during the measurements, sampling or analysis, local variations, among others, without the possibility of individual quantification of the magnitude of these components. The variables of the bed presented different values of the initial variability $\left(C_{0}\right)$, being the penetration resistance
$\left(P R_{b}\right)$ the variable with the highest occurrence of highest $C_{0}$ values in all the analyzed layers.

The bed temperature $\left(t_{b}\right)$ presented different $C_{0}$ values for both analyzed depths, surface layer and $0.2 \mathrm{~m}$ depth, with SDI values equal to 0.37 (moderate spatial dependency) and 0.82 (weak spatial dependency) for the surface and $0.2 \mathrm{~m}$ depth layers, respectively. Substantial changes in $\mathrm{C}_{0}$ for the same variable in different depths indicates a spatial distribution dependency.

Different $C_{0}$ values were obtained for the moisture of the bed $\left(M_{b}\right)$ in both layers. The moisture of the bed at the surface layer $\left(\mathrm{M}_{\mathrm{b}-\text { sur }}\right)$ shown a strong spatial dependency $\left(\mathrm{C}_{0}=0\right)$ but a moderate spatial dependency was found at 0.2 $m$ depth layer $\left(M_{b-20}\right)$ with a SDI value of 0.27 .

Regarding $\mathrm{pH}$ of the bedding material, equals $C_{0}$ values were found in both depths analyzed, at surface $\left(\mathrm{pH}_{\mathrm{b} \text {-sur }}\right)$ and $0.2 \mathrm{~m}$ depth $\left(\mathrm{pH}_{\mathrm{b}-20}\right)$, indicating a strong spatial dependency in both layer. The similarity between both semivariograms lets infer that the process that govern its distribution is similar in both depths. That is, the spatial distribution of the $\mathrm{pH}$ in both depths could be considered equal.

Table II. Estimated parameters of experimental semivariogram for each variable evaluated at the facility.

\begin{tabular}{|c|c|c|c|c|c|c|}
\hline Variable & $\mathbf{C}_{\mathbf{0}}$ & $\mathbf{C}_{\mathbf{1}}$ & $\mathbf{C}_{\mathbf{0}}+\mathbf{C}_{\mathbf{1}}$ & $\boldsymbol{a}$ & SDI & Classification \\
\hline $\mathrm{t}_{\mathrm{b} \text {-sur }}$ & 0.67 & 1.14 & 1.82 & 78.59 & 0.37 & Moderate \\
\hline $\mathrm{t}_{\mathrm{b}-20}$ & 29.98 & 6.37 & 36.34 & 49.79 & 0.82 & Weak \\
\hline $\mathrm{M}_{\mathrm{b}-\text { sur }}$ & 0.00 & 91.05 & 91.05 & 11.56 & 0.00 & Strong \\
\hline $\mathrm{M}_{\mathrm{b}-20}$ & 19.27 & 53.36 & 72.63 & 24.51 & 0.27 & Moderate \\
\hline $\mathrm{pH}_{\mathrm{b}-\text {-sur }}$ & 0.05 & 0.74 & 0.80 & 61.63 & 0.07 & Strong \\
\hline $\mathrm{PH}_{\mathrm{b}-20}$ & 0.05 & 0.63 & 0.68 & 62.82 & 0.07 & Strong \\
\hline $\mathrm{PR}_{\mathrm{b} 0-5}$ & 7715.69 & 1299.07 & 9014.76 & 66.58 & 0.86 & Weak \\
\hline $\mathrm{PR}_{\mathrm{b} 5-10}$ & 103529.17 & 13740.23 & 117269.40 & 20.08 & 0.88 & Weak \\
\hline $\mathrm{PR}_{\mathrm{b} 10-15}$ & 207940.68 & 2625.20 & 210565.88 & 46.56 & 0.98 & Weak \\
\hline $\mathrm{PR}_{\mathrm{b} 15-20}$ & 263977.96 & 28741.90 & 292719.86 & 46.34 & 0.90 & Weak \\
\hline
\end{tabular}

${ }^{*} C_{0}$ - nugget effect; $C_{1}$ - contribution; $C_{0}+C_{1}-$ sill; $a$ - range; and SDI - spatial dependence index. 
SDI values higher than 0.75 were obtained for the penetration resistance $\left(\mathrm{PR}_{\mathrm{b}}\right)$ in all the layers analyzed, showing a weak spatial dependency. The lowest spatial dependence was observed in the layer from 0.10 to $0.15 \mathrm{~m}\left(\mathrm{PR}_{\mathrm{b} 10-15}\right)$, with SDI equal to 0.98 .

The range parameter (a) was employed to determine the limit of the spatial dependence (Ferraz et al. 2017b). The range values were always highest for the shortest distance between sampling points $(>6.0 \mathrm{~m}$ ), indicating that the levels of the sampled variables are correlated with each other. It makes possible to use the ordinary kriging interpolation method to obtain their values at non-sampled points and spatial distribution maps. The lowest range value was obtained for $M_{b \text {-sur' }} 11.56 \mathrm{~m}$, higher than the distance between sample points. It should be noted that the variables that presented highest range values and closer to each other, such as the temperature and the $\mathrm{pH}$ of the bed (at both depths), can use greater distances between the sampling points, without compromising the results found.

From the models and parameters of the semivariograms fitted, it can be concluded that they do not have a random spatial distribution, as they presented spatial dependence, as well as range values higher than the distance between sampling points. In this way, it is possible to use the ordinary kriging interpolation method to predict the levels of the variables in nonsampled points and to make thematic maps of spatial distribution (Figure 2), allowing the identification of areas with the highest and lowest levels of the variables of interest and the precise management of the activities that will be applied in them (Ferraz et al. 2017b).

The temperature of the bed surface tends to the inside environment temperature, as a result of heat losses caused by ventilation, and because the wood (read sawdust and maravalha) is not a good conductor of heat (Damasceno 2020). According to the Figure $2 \mathrm{a}$, the temperature of the bed surface $\left(t_{b-s u r}\right)$ presented low variability through the facility, with 6 으 of amplitude. The region with the lowest values of $\mathrm{t}_{\mathrm{b} \text {-sur }}\left(<25^{\circ} \mathrm{C}\right)$ was observed close to the evaporative pad cooling (EPC), due to the heat exchanges between the bed surface and the cooled air (Black et al. 2013). There was a tendency to increase the bedding surface temperature along the facility due to the reduced ability of the air to remove heat from the surface. On the other hand, the region with the highest $t_{b-s u r}$ occurs close to the northwest side of the installation, coinciding with the location of lots 3, 4 and 5. Its occurrence is attributed to the filtration of hot air through the failures in the sealing of the closing side curtain, as well as through the opening of the side gates, necessary for the management of animals in the lots.

Peixoto et al. (2019) studied the thermoregulatory behavior of dairy cows submitted to bed temperature variations in compost barn facilities under semi-arid climate conditions, and observed that $\mathrm{t}_{\mathrm{b} \text {-sur }}$ in the afternoon varied between 29.0 and $31.4{ }^{\circ} \mathrm{C}$ in the dry period (October 2016), and between 28.0 and $32.4{ }^{\circ} \mathrm{C}$ in the rainy period (February 2017). The values of $t_{b-s u r}$ found in this study, which was performed in a subtropical climate (Cwa) site during the dry period (October 2017), showed the occurrence of lower values of $t_{b-s u r}(<28.0$ ${ }^{\circ} \mathrm{C}$ ) than those observed by the aforementioned authors, and indicate that climatization is effective in reducing the temperature of the bed surface.

Under adequate temperature conditions (thermoneutrality zone for dairy cattle: - 4.0 to $26.0{ }^{\circ} \mathrm{C}$ (Huber 1990)), the animals remain more than $50 \%$ of the lying time in leisure and rumination activities (Almeida et al. 2013). With this, if $t_{b-s u r}$ is kept at low levels, the animals will remain lying down longer, reducing energy 


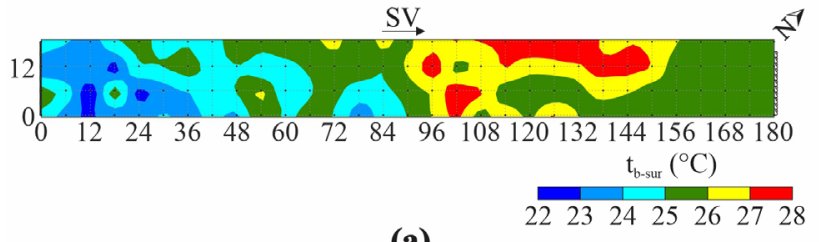

(a)

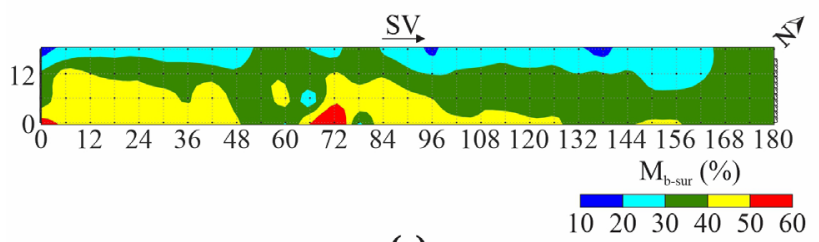

(c)

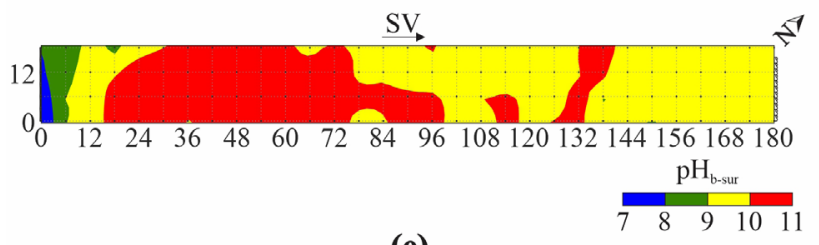

(e)

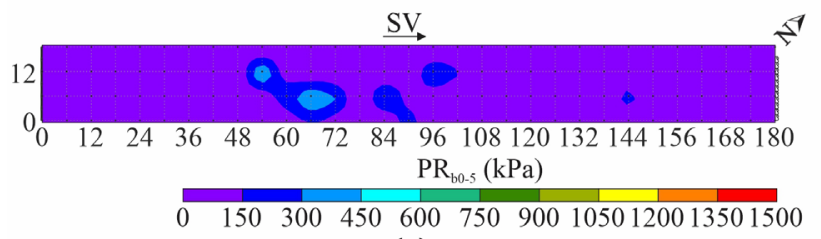

(g)

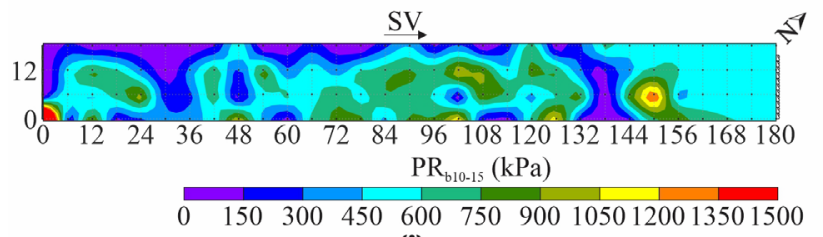

(i)

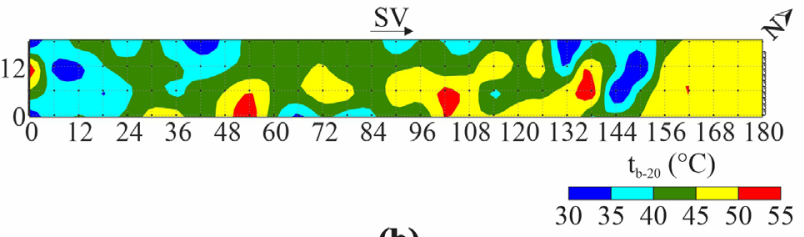

(b)

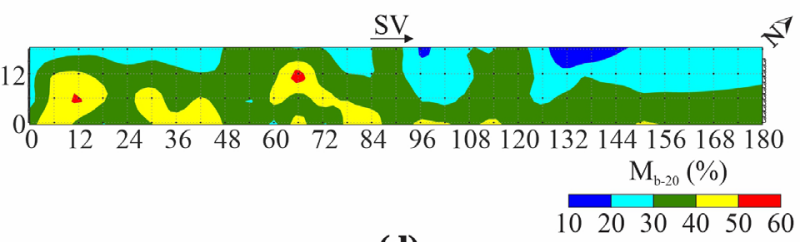

(d)

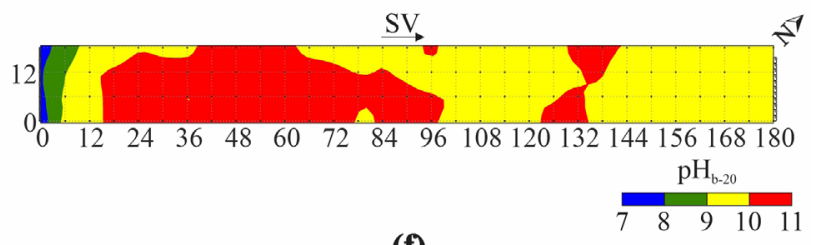

(f)

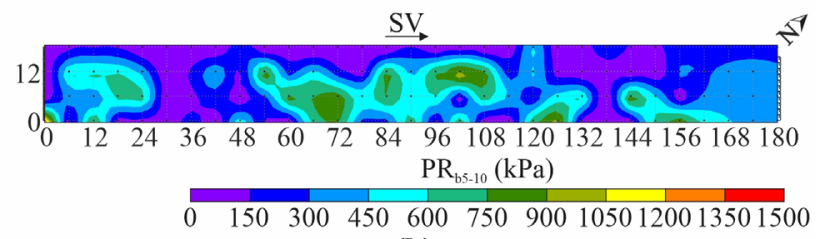

(h)

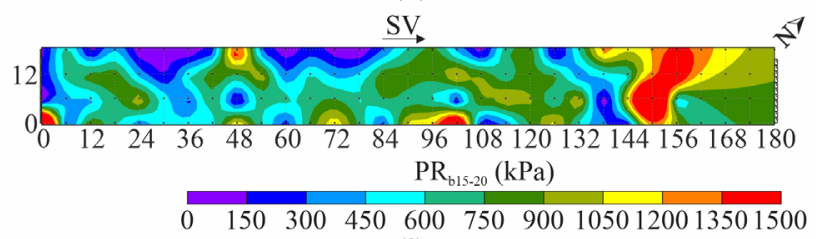

(j)

Figure 2. Spatial distribution of the variables: $(a)$ bedding surface temperature $\left(t_{b-s u r}\right) ;(b)$ bedding temperature at $0.20 \mathrm{~m}$ depth $\left(\mathrm{t}_{\mathrm{b}-20}\right) ;(\mathrm{c})$ bedding surface moisture $\left(\mathrm{M}_{\mathrm{b}-\mathrm{sur}}\right) ;(\mathrm{d})$ bedding moisture at $0.20 \mathrm{~m}$ depth $\left(\mathrm{M}_{\mathrm{b}-20}\right) ;$ (e) bedding surface $\mathrm{pH}\left(\mathrm{pH}_{\mathrm{b}-\text { sur }}\right) ;$ ( $\left.\mathrm{f}\right)$ bedding $\mathrm{pH}$ at $0.20 \mathrm{~m}$ depth $\left(\mathrm{pH}_{\mathrm{b}-20}\right) ;(\mathrm{g})$ bedding penetration resistance at 0 to $0.05 \mathrm{~m}$ depth $\left(\mathrm{PR}_{\mathrm{b} 0-5}\right)$; $(\mathrm{h})$ bedding penetration resistance at 0.05 to $0.10 \mathrm{~m}$ depth $\left(\mathrm{PR}_{\mathrm{b} 5-10}\right)$; (i) bedding penetration resistance at 0.10 to $0.15 \mathrm{~m}$ depth $\left(\mathrm{PRb}_{10-15}\right) ;(\mathrm{j})$ bedding penetration resistance at 0.15 to $0.20 \mathrm{~m}$ depth $\left(\mathrm{PR}_{\mathrm{b} 15-20}\right)$. * $\mathrm{SV}$ - sense of ventilation.

expenditure, and increasing their productivity. On the other hand, if the $t_{b-s u r}$ is high, heat exchanges can occur by conduction between the bed surface and the animal, which causes an increase in the temperature of its body nucleus and a reduction in the time that the animal remains lying. The results show that the $t_{b-s u r}$ throughout the installation was less than 26 으, providing an adequate thermal comfort environment for the animals while lying.
The temperature of the bed at $0.2 \mathrm{~m}$ depth $\left(t_{b-20}\right)$ increased (Figure $\left.2 b\right)$ due to the higher activity of decomposing microorganisms in the aerobically active layer ( 0.15 to $0.20 \mathrm{~m}$ ), increasing the exothermic heat generation (Janni et al. 2007). The lower levels of $t_{b-20}$ where found in the peripheral regions of the facility (close to the EPC) and in the intermediate area between the lots 4 and 5. In the peripheral region of the installation, there was difficult to performing 
maneuvers with the tractor to stirring the bed, generating a compaction of it and a reduction in oxygen concentrations available to decomposing microorganisms, reducing their activity and, consequently, causing lower levels of $t_{b-20}$ (Rink et al. 1992). Close to the EPC, the lower levels of $t_{b-20}$ were due to the cold air intake, which reduces the temperature over the depth of the bed.

Acording to Rebollido et al. (2008), the temperature in the bed surface is a determinant factor in the composting process since it is responsible for the succession of microbial populations and their representativeness during the process of material degradation. The ideal range of temperature at the aerobically active layer ( 0.15 to $0.20 \mathrm{~m}$ ) is between 54 and 65 oC, rising by an increasing microbial activity due to a higher heat production (Janni et al. 2007). Temperature values higher than 45 o $\mathrm{C}$ also allow the maintenance of the composting process, however, temperatures lower than 40 oc indicates minimal microbial activity and, consequently, slow rate of composting (Shane et al. 2010). The results show a slow decomposition rate of the bedding material in the region close to the EPC and in the peripheral of the facility due to $t_{b-20}$ values lower than 40 으.

The surface moisture of the bed $\left(M_{b-}\right.$ sur) showed high spatial variability, with an amplitude of $50 \%$. Inside the facility, it was observed a tendency to show the highest levels of moisture in the area close to the feed alley, presumably because animals spill water after drinking. Also, there is an increase in feces and urine in this area because animals stay longer due to the location of the feeders and drinkers, contributing to the increase in the bed moisture. The higher levels of $M_{b-s u r}$ were found in the lots 1 and 2, lots with the higher milk production and consequently high production of waste (Campos et al. 2002, ASAE 2003). On the other hand, the lowest levels occurred along the northwest side of the facility, due to the filtration of hot and dry air coming from outside.

Because the activity of decomposing microorganisms is reduced in the surface layer, $M_{b-s u r}$ receives greater importance in relation to health of the animals, since it has a direct relationship with the dirt of animals. According to Radostits et al. (1994), bed temperature and moisture influence the susceptibility to mastitis. Excess moisture makes the udder and teats of the animals dirtier, increasing the possibility of environmental contamination and the incidence of mammary gland infection. In this way, the management of the CBP must guarantee the formation of areas with adequate moisture, keeping the animals clean to reduce the occurrence of mammary gland infection. Low moisture values ( $<50 \%$ - Figure $2 \mathrm{c}$ ) on the surface of the bed is desirable, and it is estimated that its will provide better health conditions for the animals.

The spatial distribution of moisture at a depth of $0.20 \mathrm{~m}\left(\mathrm{M}_{\mathrm{b}-20}\right)$ was similar to that observed on the surface (Figure 2d). The highest levels of $M_{b-20}$ occurred in the region near the feed alley, while the lowest levels on the northwest side of the facility, indicating that the moisture distribution in the subsurface layer of the bed is influenced by $M_{b-s u r}$ due to the filtration of water through the bed.

For a satisfactory composting process on the aerobically active layer ( 0.15 to $0.20 \mathrm{~m}$ ), a value of moisture between 40 to $65 \%$ is required (Shane et al. 2010). The $M_{b-20}$ was lower than 40\% along the facility area, making that the process of decomposition of the bedding material occurs slowly due to the lower degree of activity of the decomposing microorganisms (Figure $2 \mathrm{~d}$ ).

The distribution of the $\mathrm{pH}$ at the bed surface $\left(\mathrm{pH}_{\mathrm{b} \text {-sur }}\right)$ shows a high spatial variability with an amplitude of 4 (Figure 2e). Values close 
to 7 were found in the region close to the EPC, due to the frequent replacement of the bedding material in this zone to reduce the highest levels of moisture in the bed due to the water fall from the EPC. Once the composting process begins, organic acids are released due to the initial decomposition of organic matter by fungi and bacteria, lowering the $\mathrm{pH}$ levels (Bernal et al. 2009, Hanajima et al. 2010). It is noted that the lower degree of degradation of the bed material in this region is due to the inability to maintain the appropriate levels of temperature and moisture for the composting process.

In advanced stages of the composting process, acids formed in the initial stage decompose to complete oxidation, raising the $\mathrm{pH}$ of the material to alkaline levels in the final stage (Hanajima et al. 2010). The $\mathrm{pH}_{\mathrm{b} \text {-sur }}$ levels along the facility were higher than 9, indicating that the composting process was already at an advanced state (Zhang et al. 2019). The higher $\mathrm{pH}$ values were mainly present in the lots with the least area available per animal (lots 2 and 3) that leads to a greater deposit of feces and urine per area, generating greater availability and mineralization of nitrogen $(\mathrm{N})$. High $\mathrm{pH}$ values also indicates $\mathrm{N}$ losses by ammonia volatilisation, which may be particularly high if the $\mathrm{pH}$ is greater than 7.0 (Bernal et al. 2009).

The distribution of $\mathrm{pH}$ at $0.2 \mathrm{~m}$ depth $\left(\mathrm{pH}_{\mathrm{b}}\right.$ ${ }_{20}$ ) was similar to the observed in the surface layer of the bed, indicating that the phenomena that govern the distribution of $\mathrm{pH}$ in the bed are similar in both layers. This corroborates what the geostatistical parameters indicate (Figure $2 f$ ). The results show that the decomposition of the organic matter occurs in a similar way along the depth of the bed, generating a composting with uniform agronomic characteristics along the profile of the bed.

Regard to the penetration resistance of the bed $\left(\mathrm{PR}_{\mathrm{b}}\right)$, it was observed an increasing along the profile of the bed, with the highest values in the layer between 0.15 to $0.20 \mathrm{~m}$ depth.

In the layer between 0 and $0.05 \mathrm{~m}$ depth, the penetration resistance $\left(\mathrm{PR}_{\mathrm{b} 0-5}\right)$ presented a uniform spatial distribution along the facility, being always less than $450 \mathrm{kPa}$. This indicates that the stirring tool used is effective to promote the rupture and homogenization of the bed material in this layer (Figure 2g). The $\mathrm{PR}_{\mathrm{b} 05}$ values were higher than $150 \mathrm{kPa}$ only in the region where were located the lots 2 and 3. In these lots there was a smaller area available per animal (9.4 and $9.2 \mathrm{~m}^{2}$.animal ${ }^{-1}$, respectively), causing a greater trampling of the bed with increase of the $\mathrm{PR}_{\mathrm{b}}$.

In the layer between 0.05 and $0.1 \mathrm{~m}$ depth, the map of spatial distribution of the penetration resistance $\left(\mathrm{PR}_{\mathrm{b5} 10}\right)$ showed an increasing in the variability, with values between 0 and $1050 \mathrm{kPa}$ (Figure $2 \mathrm{~h}$ ). The higher values were observed in the area where the lots 1, 2 and 3 were located, as well as in some regions close to the feed alley. It is observed that $\mathrm{PR}_{\mathrm{b510}}$ is function of the smallest area available per animal (lots 2 and 3), as well as of the high moisture of the bed (lot 1). High levels of moisture and a continuous passage of animals caused greater compaction due to the application of concentrated loads in small areas that characterize these regions.

The tendency of higher $\mathrm{PR}_{\mathrm{b}}$ continue in the layer between 0.10 and $0.15 \mathrm{~m}$ depth, presenting high penetration resistance and spatial variability, with values between 0 and $1500 \mathrm{kPa}$ (Figure 2i). In this layer, the highest values were observed in the peripheral region, where the stirring process is difficult and the compacted structures are impossible to break; and close to the feed alley where a high level of moisture is detected and a continuous passage of animals is registred.

In the layer between 0.15 and $0.20 \mathrm{~m}$ depth (Figure 2j) a significative area with high $\mathrm{PR}_{\mathrm{b}}$ was observed (>1000 kPa), located between the lots 5 
and pre-calving. Since these lots had an area per animal greater than the minimum recommended for large animals $\left(9.3 \mathrm{~m}^{2}\right.$ animal ${ }^{-1}$ (Bewley et al. 2012)), it is estimated that their occurrence is due to a bad stirring of the bed, which caused the formation of a compacted subsurface layer.

Since the spatial distribution maps do not present detailed numerical information about the area fractions occupied by each of the classes of the variables evaluated, frequency distribution graphs were employed, as shown in Figure 3.

In $74.1 \%$ of the bed area, the $t_{b-s u r}$ was less than $26{ }^{\circ} \mathrm{C}$ (Figure 3a), indicating that the conditions found were propitious for the thermal comfort of the animals. On the other hand, in $25.1 \%$ of the area, $t_{b-s u r}$ was higher than the upper critical temperature limit for lactating Holstein cows and, therefore, animals tend to not lying down in that region. At 0.20 depth, the $t_{b-20}$ was less than $40{ }^{\circ} \mathrm{C}$ in $25 \%$ of the bed area, which means that

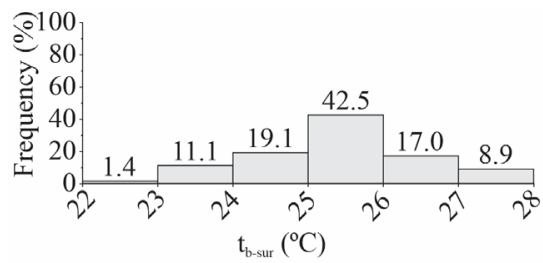

(a)

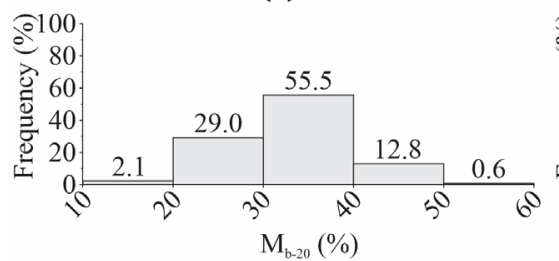

(d)

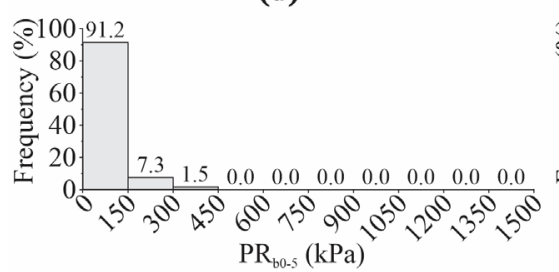

(g)

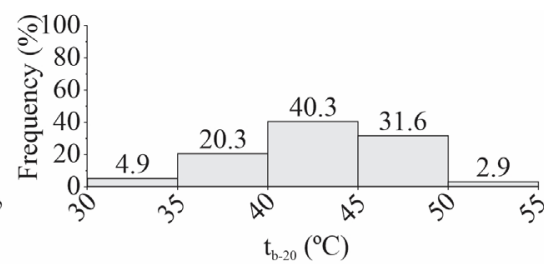

(b)

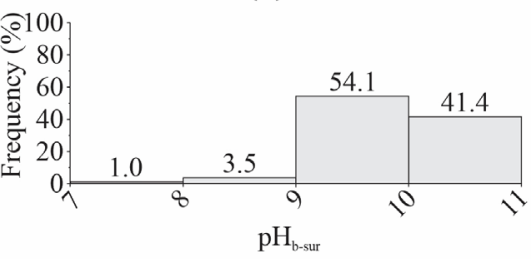

(e)

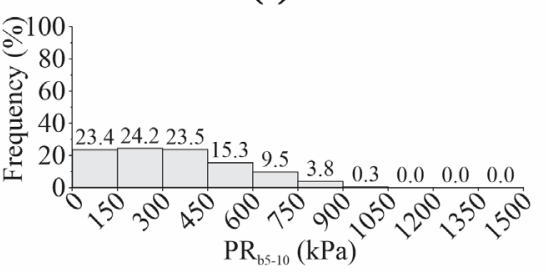

(h)

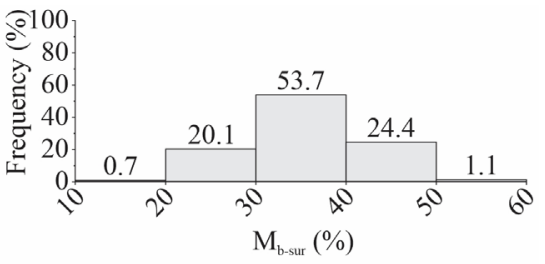

(c)

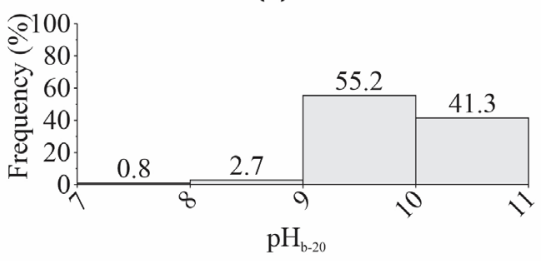

(f)

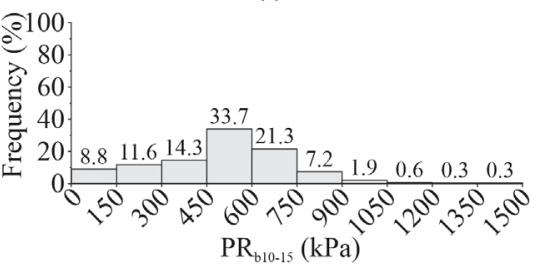

(i)

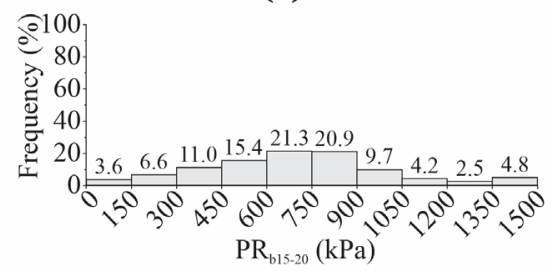

(j)

Figure 3. Frequency distribution of the variables: $(a)$ bedding surface temperature $\left(t_{b_{\text {_sur }}}\right)$; $(b)$ bedding temperature at $0.20 \mathrm{~m}$ depth $\left(\mathrm{t}_{\mathrm{b}_{2} 20}\right) ;(\mathrm{c})$ bedding surface moisture $\left(\mathrm{M}_{\mathrm{b}_{2} \text { sur }}\right) ;(\mathrm{d})$ bedding moisture at $0.20 \mathrm{~m}$ depth $\left(\mathrm{M}_{\mathrm{b}_{2} 20}\right) ;(\mathrm{e})$ bedding surface $\mathrm{pH}\left(\mathrm{pH}_{\mathrm{b} \text { sur }}\right) ;(\mathrm{f})$ bedding $\mathrm{pH}$ at $0.20 \mathrm{~m}$ depth $\left(\mathrm{pH}_{\mathrm{b}_{2} 0}\right) ;(\mathrm{g})$ bedding penetration resistance between 0 and $0.05 \mathrm{~m}$ depth $\left(\mathrm{PR}_{\mathrm{b} 0-5}\right) ;(\mathrm{h})$ bedding penetration resistance between 0.05 and $0.10 \mathrm{~m}$ depth $\left(\mathrm{PR}_{\mathrm{b} 5-10}\right)$; $(\mathrm{i})$ bedding penetration resistance between 0.10 and $0.15 \mathrm{~m}$ depth $\left(\mathrm{PR}_{\mathrm{b} 10-15}\right) ;(\mathrm{j})$ bedding penetration resistance between 0.15 and $0.20 \mathrm{~m}$ depth $\left(\mathrm{PR}_{\mathrm{b} 15-20}\right)$. 
the bed composting process in this layer occurs more slowly and that the compost obtained may not have good agronomic characteristics, due to the non-elimination of pathogens.

The frequency distributions of bed moisture at the surface and at a depth of $0.20 \mathrm{~m}$ were very similar, concentrating between $20 \%$ and $50 \%$ (Figures $3 c-d$ ). In the surface, the $M_{b-s u r}$ was greater than $50 \%$ in just $1.1 \%$ of the bed area and, therefore, it is estimated that there will be less dirt in the animals because mud is not created and susceptibility of animals to mastitis will be lower (Radostits et al. 1994). On the other hand, the $M_{b-20}$ was predominantly less than $40 \%$, the minimum level recommended for decomposing activity (Shane et al. 2010). In just $13.4 \%$ of the bed area the moisture was higher than that level and, thus, the decomposition of the bedding material in this installation occurs in a slower and uneven manner, according to the conditions presented.

With respect to the bedding $\mathrm{pH}$ material, it was observed that the frequency distributions for the surface and for $0.20 \mathrm{~m}$ depth were similar. The $\mathrm{pH}$ was greater than 9 in more than $95 \%$ of the bed area, being classified as strongly alkaline (Figures 3e-f).

In general, the process of composting the bed material in a CBP facility occurs over a period of one year. It can be accelerated or delayed depending on the material used, the number of animals, the adopted handling and the frequency of replacement of the bed. According to Kiehl (2002), in the large-scale composting process, the $\mathrm{pH}$ starts acid and becomes alkaline (about 9.0) when it reaches full decomposition of the material. The $\mathrm{pH}$ remains at this level as long as there is ammoniacal nitrogen. When it passes to the nitrate form, there is a reduction in the $\mathrm{pH}$ value. The results found in this study behaved according to the author, since they were higher than 9.0. High $\mathrm{pH}$ values found indicate that the material is in the final stage of the composting process, as well as the presence of ammoniacal nitrogen.

On the 0 to $0.05 \mathrm{~m}$ layer, the $\mathrm{PR}_{\mathrm{b} 0-5}$ values were relatively low, less than $300 \mathrm{kPa}$ at $98.5 \%$ of the bed area, indicating that the stirring of the bed surface was satisfactory to promote the rupture of compacted structures (Figure 3g). However, there was an increase in PRb values at increasing the depth. The 0.05 to 0.10 $\mathrm{m}$ layer showed values between $300 \mathrm{kPa}$ and $750 \mathrm{kPa}$ in $48.3 \%$ of the bed, and greater than $750 \mathrm{kPa}$ in $10.3 \%$ and $42.1 \%$ of the bed areas in the layers from 0.10 to $0.15 \mathrm{~m}$ and 0.15 to 0.20 $\mathrm{m}$, respectively (Figures $3 \mathrm{~h}-\mathrm{j}$ ). The occurrence of higher $\mathrm{PR}_{\mathrm{b}}$ values in the deeper layers may be indicative of the formation of "plow-foot", which is formed when the stirring is always carried out at the same depth (Castro et al. 2009).

Despite the importance of the porosity of the bed to oxygenate it properly and contribute to microbial activity (Chang et al. 2006), there is no standard that can be used for comparing $\mathrm{PR}_{\mathrm{b}}$ values, and it is not possible to classify it as appropriate or not. However, the results found allow to infer that bed compaction in this installation did not significantly affect the oxygen supply to the decomposing microorganisms, since the other variables evaluated showed an advanced state of decomposition of the material (Hanajima et al. 2010). The correction of bed stirring failures, especially in regions with higher levels of $\mathrm{PR}_{\mathrm{b}}$, would be sufficient to reduce it.

\section{CONCLUSIONS}

The geostatistic method show a spatial dependency of the variables studied, being strong for $\mathrm{M}_{\mathrm{b} \text {-sur' }} \mathrm{pH}_{\mathrm{bsur}}$ and $\mathrm{pH}_{\mathrm{b}-20^{\prime}}$, moderate for $t_{b-s u r}$ and $M_{b-20}$ and weak for the others variables. The spatial distribution maps of the surface 
variables of the bed showed the presence of goods levels of tb-sur, Mb-sur and PRb, indicating adequate conditions of comfort so the animals remain lying, as well as a low microbial activity on the surface.

At $0.20 \mathrm{~m}$ depth, temperature and moisture of the bed were measured. Values lower than those required by decomposicion microorganisms were obtained, indicating that the process of bed degradation in the installation is slow. On the other hand, the $\mathrm{pH}$ of the bed at surface and at 0.20 m depth were higher than 9, a strong indication that the decomposition of the bed material was already in the final stage. $P R_{b}$ values increase with depth. Areas with high $\mathrm{PR}_{\mathrm{b}}$ values and higher moisture were found in the facility, located where the passage of animals is frequent, as well as at the ends, due to less stirring of the bed.

Spatial distribution for bedding variables in compost bedded pack barns can be easily reproduced through the use of Geostatistics technique, reducing the number of field experiments. The developed computational simulation and methodology allow highlighting the zones with low bed temperature and high moisture, making possible to determine if the bed management is in agreement with the requirements of the composting process.

\section{Acknowledgments}

The authors express their appreciation to the hosts institutions, Universidade Federal de Lavras (Brazil) and Universidade Federal de Viçosa (Brazil). This study was supported by the Conselho Nacional de Desenvolvimento Científico e Tecnológico (CNPq), Coordenação de Aperfeiçoamento de Pessoal de Nivel Superior (CAPES) and the Fundação de Amparo à Pesquisa do Estado de Minas Gerais (FAPEMIG).

\section{REFERENCES}

ALMEIDA GLP, PANDORFI H, BARBOSA SBP, PEREIRA DF, GUISELINI C \& ALMEIDA GAP. 2013. Comportamento, produção e qualidade do leite de vacas Holandês-Gir com climatização no curral. Rev Bras Eng Agríc Ambient 17(8): 892-899.

ASAE - AMERICAN SOCIETY OF AGRICULTURAL ENGINEERS. 2003. Manure Production and Characteristics. ASAE Standards, n. 50. St. Joseph: ASAE, 20 p.

BACHMAIER M \& BACKERS M. 2008. Variogram or semivariogram? Understanding the variances in a variogram. Precis Agric 9(3): 173-175.

BERNAL MP, ALBURQUERQUE JA \& MORAL R. 2009. Composting of animal manures and chemical criteria for compost maturity assessment. A review. Bioresour Technol 100(22): 5444-5453.

BEWLEY JM, TARABA JL, DAY GB, BLACK RA \& DAMASCENO FA. 2012. Compost bedded pack barn design features and management considerations. Cooperative Extension Publ., ID-206. Lexington: University of Kentucky College of Agriculture, $32 \mathrm{p}$.

BLACK RA, TARABA JL, DAY GB, DAMASCENO FA \& BEWLEY JM. 2013. Compost bedded pack dairy barn management, performance, and producer satisfaction. J Dairy Sci 96(12): 8060-8074.

CAMBARDELLA CA, MOORMAN TB, NOVAK JM, PARKIN TB, KARLEN DL, TURCO RF \& KONOPKA AE. 1994. Field-scale variability of soil properties in Central Iowa soils. SSSA Journal 58(5): 1501-1511.

CAMPOS AD, FERREIRA WA, PACCOLA AA, LUCAS JÚNIOR JD, ULBANERE RC, CARDOSO RM \& CAMPOS AT. 2002. Aerobic biological treatment and recycling of bovine manure in intensive system of milk production. Cienc Agrotec 26: 426-438.

CASTRO OM, VIEIRA SR, SIQUEIRA GM \& ANDRADE CA. 2009. Atributos físicos e químicos de um Latossolo Vermelho eutroférrico sob diferentes sistemas de preparo. Bragantia 68(4): 1047-1057.

CHANG JI, TSAI JJ \& WU KH. 2006. Composting of vegetable waste. Waste Manag Res 24(4): 354-362.

DAMASCENO FA. 2020. Compost barn como uma alternativa para a pecuária leiteira, 1. ed. Divinópolis: Adelante, 396 p.

DAMASCENO FA, OLIVEIRA CEA, FERRAZ GAS, NASCIMENTO JAC, BARBARI M \& FERRAZ PFP. 2019. Spatial distribution of thermal variables, acoustics and lighting in compost 
dairy barn with climate control system. Agron Res 17(2): 385-395.

FARIA FF, MOURA DJ, SOUZA ZS \& MARATAZZO SV. 2008. Variabilidade espacial do microclima de um galpão utilizado para confinamento de bovinos de leite. Cienc Rural 38(9): 2498-2505.

FERRAZ GAS, SILVA FM, OLIVEIRA MS, CUSTÓDIO AAP \& FERRAZ PFP. 2017a. Variabilidade espacial dos atributos da planta de uma lavoura cafeeira. Rev Ciênc Agron 48(1): 81-91.

FERRAZ PFP, GONZALEZ VC, FERRAZ GAS, DAMASCENO FA, OSORIO JAS \& CONTI L. 2020. Assessment of spatial variability of environmental variables of a typical house of laying hens in Colombia: Antioquia state Case. Agron Res 18(2): $1244-1254$.

FERRAZ PFP, YANAGI JUNIOR T, FERRAZ GAS \& DAMASCENO FA. 2017b. Distribuição espacial do índice de temperatura do globo e umidade em galpão de frangos na primeira semana de vida aquecido por fornalha industrial. Energ Agric 32(4): 356-363.

FERRAZ PFP, YANAGI JUNIOR T, FERRAZ GAS, SCHIASSI L \& CAMPOS AT. 2016. Spatial variability of enthalpy in broiler house during the heating phase. Rev Bras Eng Agric Ambient 20(6): 570-575.

HANAJIMA D, KURODA K, MORISHITA K, FUJITA J, MAEDA K \& MORIOKA R. 2010. Key odor components responsible for the impact on olfactory sense during swine feces composting. Bioresour Technol 101(7): 2306-2310.

HUBER JT. 1990. Alimentação de vacas de alta produção sob condições de estresse térmico. In: Bovinocultura leiteira, 1ạ ed., Piracicaba: FEALQ, p. 33-48.

JANNI KA, ENDRES MI, RENEAU JK \& SCHOPER WW. 2007. Compost dairy barn layout and management recommendations. Appl Eng Agric 23(1): 97-102.

LESO L, BARBARI M, LOPES MA, DAMASCENO FA, GALAMA P, TARABA JL \& KUIPERS A. 2020. Invited review: Compostbedded pack barns for dairy cows. J Dairy Sci 103(2): 1072-1099.

LESO L, UBERTI M, MORSHED W \& BARBARI M. 2013. A survey of Italian compost dairy barns. J Agr Eng 44(3): 120-124.

LOBECK KM, ENDRES MI, SHANE EM, GODDEN SM \& FETROW J. 2011. Animal welfare in cross-ventilated, compostbedded pack, and naturally ventilated dairy barns in the upper Midwest. J Dairy Sci 94(11): 5469-5479.

KIEHL ED. 2002. Manual da Compostagem: maturação e qualidade do composto, 3a ed., Piracicaba: FEALQ, 171 p.
MARCHANT BP \& LARK RM. 2007. Robust estimation of the variogram by residual maximum likelihood. Geoderma 140(1): 62-72.

MASSARI JM, MOURA DJ, CURI TMRC, VERCELLINO RA \& MEDEIROS BBL. 2016. Zoning of environmental conditions inside a wean-to-finish pig facility. Eng Agríc 36(5): 739-748.

MATHERON G. 1962. Traité de géostatistique appliquée, n. 14. Paris: Editions Technip, 333 p.

MEDEIROS BBL, MOURA DJ, MASSARI JM, CARVALHO TMR \& MAIA APA. 2014. Uso de geoestatística na avaliação de variáveis ambientais em galpão de suínos criados em sistema 'wean to finish' na fase de terminação. Eng Agríc 34(5): 800-811.

PEIXOTO MSM, BARBOSA FILHO JAD, MACHADO NAF, VIANA VSS \& COSTA JFM. 2019. Thermoregulatory behavior of dairy cows submitted to bedding temperature variations in Compost barn systems. Biol Rhythm Res 1-10.

PERISSINOTTO M, MOURA DJ, CRUZ VF, SOUZA SRL, LIMA KAO \& MENDES AS. 2009. Conforto térmico de bovinos leiteiros confinados em clima subtropical e mediterrâneo pela análise de parâmetros fisiológicos utilizando a teoria dos conjuntos fuzzy. Cienc Rural 39(5): 1492-1498.

PILATTI JA \& VIEIRA FMC. 2017. Environment, behavior and welfare aspects of dairy cows reared in compost bedded pack barns system. J Anim Behav Biometeorol 15(3): 97-105.

R DEVELOPMENT CORE TEAM. 2016. R: A language and environment for statistical computing. Vienna: $R$ Foundation for Statistical Computing. Available: http:// www.R-project.org/. Accessed in 09 October 2019.

RADOSTITS OM, LESLIE KE \& FETROW J. 1994. Herd health: Food Animal Production Medicine, 2a ed., Philadelphia: Saunders Elsevier, 233 p.

REBOLLIDO R, MARTÍNEZ J, AGUILERA Y, MELCHOR K, KOERNER I \& STEGMANN R. 2008. Microbial populations during composting process of organic fraction of municipal solid waste. Appl Ecol Env Res 6(3): 61-67.

RIBEIRO JUNIOR PJ \& DIGGLE PJ. 2001. GeoR: a package for geostatistical analysis. R-News 1(2): 14-18.

RIBEIRO PAP, YANAGI JUNIOR T, OLIVEIRA DD, FERRAZ GAS \& LOURENCONI D. 2016. Geostatistical analysis of illuminances in poultry for laying hens equipped with compact fluorescent and led lamps. Eng Agric 36(1): 11-21.

RINK R ET AL. 1992. On-Farm Composting Handbook, n. 54, Ithaca: NRAES, 186 p.

SALES FA, BARBOSA FILHO JAD, AQUINO TMF, BRITO IF \& CARVALHO LE. 2011. Monitoramento ambiental do perfil 
horizontal de um galpão para suínos, na fase de gestação, utilizando zootecnia de precisão. Rev Cient Prod Anim 13(1): 7-12.

SHANE EM, ENDRES MI \& JANNI KA. 2010. Alternative bedding materials for compost bedded pack barns in Minnesota: a descriptive study. Appl Eng Agric 26(3): 465-473.

TEIXEIRA PC, DONAGEMMA GK, FONTANA A \& TEIXEIRA WG. 2017. Manual de métodos de análise de solo, 3a ed., Brasília: Embrapa, 573 p.

YAMAMOTO JK \& LANDIM PMB. 2015. Geoestatística: conceitos e aplicações, 1ạ ed., São Paulo: Oficina de textos, 215 p.

ZHANG Q, LIU J, GUO H, LI E \& YAN Y. 2019. Characteristics and optimization of dairy manure composting for reuse as a dairy mattress in areas with large temperature differences. J Clean Prod 232: 1053-1061.

ZHAO S, LIU X \& DUO L. 2012. Physical and Chemical Characterization of Municipal Solid Waste Compost in Different Particle Size Fractions. Pol J Environ Stud 21(2): 509-515.

\section{How to cite}

OLIVEIRA CEA, DAMASCENO FA, FERRAZ GAS, DO NASCIMENTO JAC, VEGA FAO, TINÔCO IFF \& ANDRADE RR. 2021. Assessment of spatial variability of bedding variables in compost bedded pack barns with climate control system. An Acad Bras Cienc 93: e20200384. DOI 10.1590/00013765202120200384.

Manuscript received on March 19, 2020;

accepted for publication on July 28, 2020

CARLOS EDUARDO A. OLIVEIRA ${ }^{1}$

https://orcid.org/0000-0002-2104-7428

FLÁVIO A. DAMASCENO ${ }^{2}$

https://orcid.org/0000-0002-8284-7496

GABRIEL A.S. FERRAZ ${ }^{2}$

https://orcid.org/0000-0001-6403-2210
JOÃO ANTÔNIO C. DO NASCIMENTO3

https://orcid.org/0000-0001-5984-5997

\section{FELIPE A.O. VEGA ${ }^{4}$}

https://orcid.org/0000-0001-7241-7065

\section{ILDA F.F. TINÔCO ${ }^{1}$}

https://orcid.org/0000-0002-8152-0301

\section{RAFAELLA R. ANDRADE ${ }^{1}$}

https://orcid.org/0000-0003-3182-0741

${ }^{1}$ Universidade Federal de Viçosa, Departamento de Engenharia Agrícola, Av. Peter Henry Rolfs, s/n, Campus Universitário, 36570-900 Viçosa, MG, Brazil

${ }^{2}$ Universidade Federal de Lavras, Departamento de Engenharia, Av. Doutor Sylvio Menicucci, 1001, Aquenta Sol, 37200-000 Lavras, MG, Brazil

${ }^{3}$ Universidade Federal de Lavras, Departamento de Zootecnia, Av. Doutor Sylvio Menicucci, 1001, Aquenta Sol, 37200-000 Lavras, MG, Brazil

${ }^{4}$ Facultad de Ciencias Agrarias, Universidad Nacional de Colombia - Sede Medellín, CRA 65 \#59A-110, 050034, Medellín, Antioquia, Colombia

Correpondence to: Carlos Eduardo Alves Oliveira

E-mail: carloseaoliveira@hotmail.com

\section{Author contributions}

Carlos Eduardo Alves Oliveira, Flávio Alves Damasceno and João Antônio Costa do Nascimento conducted the field trials, collected and data analysis, and wrote the manuscript. Gabriel Araújo e Silva Ferraz and Felipe Andrés Obando Vega helped on data analysis. Ilda de Fátima Ferreira Tinôco and Rafaella Resende Andrade reviewed the manuscript.

\section{(c) $B Y$}

